\title{
Kołysanka budząca genologię
}

Piotr Michałowski 


\section{Kołysanka budząca genologię}

Piotr Michałowski

TEKSTY DRUGIE 2017, NR 5, S. 185-194

DOI: 10.18318/td.2017.5.12

$\mathbf{N}$ iewiele ukazuje się monografii poszczególnych gatunków literackich. Jeszcze mniej tak wnikliwych i obszernych, jak książka Katarzyny Wądolny-Tatar Kołysanka w liryce XX $i$ XXI wieku. A zwłaszcza - omawiających gatunki, o których dziwnie zapomniały słowniki terminologii literackiej, chociaż ich istnienia nie zakwestionuje nawet - jak w tym wypadku - przedszkolak. Chodzi bowiem o kołysankę.

Oczywistym punktem wyjścia w monografii genologicznej musi być definicja gatunku. Klasyczna, nowoczesna lub ponowoczesna. Sformułowana polemicznie, wybrana spośród konkurencyjnych propozycji lub skompilowana. Historyczna albo ponadczasowa. Natomiast w przypadku kołysanki musi mieć ona charakter niejako roboczy - wobec zagadkowego braku terminu w leksykonach - pominiętego zresztą podobnie jak „erotyk”. Nie

1 Recenzja: K. Wądolny-Tatar Kołysanka w liryce XX i XXI wieku. Emergencja gatunku literackiego, Wydawnictwo Naukowe Uniwersytetu Pedagogicznego, Kraków 2014.
Piotr

Michałowski dr hab., kierownik

Zakładu Teorii

i Antropologii

Literatury Uniwersytetu Szczecińskiego.

Ostatnio opublikował m.in. książki: Mikrokosmos wiersza. Interpretacje poezji współczesnej (2012) i Narożnikowo, centralnie, pogranicznie. Szkice szczecińskie i europejskie (2014) oraz zredagował tom zbiorowy Od pióra do sieci.Zmienne media literatury (2015). 
wiadomo, czy pominięcie to wynika ze zwykłego przeoczenia, czy przemyślanej eksmisji kołysanki z literatury?

Katarzyna Wądolny-Tatar nie zatrzymuje się dłużej nad tą tajemnicą, a skupia się na reakcji pozytywnej. Próbując wypełnić dotkliwą pustkę, określa najpierw „bazowe” cechy gatunku. Należy do nich układ komunikacyjny uwarunkowany koniecznością kontaktu ,ja” i „ty” oraz bezpośredniość wpływu w celu wywołania senności, a wreszcie stanu snu. Chodzi zatem o swoistą lirykę apelu, przy czym jednak w kołysance literackiej, która jest właściwym przedmiotem badania, musi to być jedynie imitowanie cech ludowego źródła, a więc pojawia się już inny cel komunikacyjny. Zazwyczaj akcent zostaje przeniesiony na ekspresję „ja” - co z kolei zbliża wypowiedź do liryki wyznania. Ciężar odpowiedzialności za podobieństwo z pierwotną formą spada zatem na poziom stylu i wersyfikacji - rytmiczność wiersza (często sylabotonizm), powtórzenia, paralele, niekiedy również enumeracje.

Nie tyle przeoczony, ile nieco rozmyty i słabo wyeksponowany wydaje się jednak nadrzędny paradoks komunikacyjny, który ustanawia specyfikę kołysanki. Otóż, skoro jej celem - założonym przynajmniej w ludowym praźródle - ma być usypianie słuchacza, czyli doprowadzenie go do stanu percepcji zerowej, to tenże słuchacz wskutek przerwania kontaktu powinien utracić kompetencje odbiorcy jeszcze w trakcie nadawania - oczywiście, jeśli wykluczyć stany hipnotyczne i możliwość oddziaływania na podświadomość. Kołysanka istnieje więc wprawdzie po to, by zarówno ułatwiła zaśnięcie, jak i programowała pozytywną treść nadchodzącego snu, lecz również zakłada swe niedokończenie w przekazie ustnym, czyli wykonaniu. Tu właśnie kończy się analogia z literacką mutacją gatunku, gdyż usypianego zastępuje czytelnik, będący w założeniu odbiorcą całości tekstu. Podobieństwo obejmować może jednak nie tylko rytmiczne redundantne powtórzenia, ale i brak puenty czy wręcz programową antypuentowość, fingującą niedomknięcie utworu, jego dalsze przemilczane trwanie lub możliwość repetycji da capo al fine. Wprawdzie pośrednio autorka parokrotnie wspomina, że dla usypianego małego "odbiorcy" przeznaczony był jedynie rytm (towarzyszący ruchowi kołyski), natomiast niezrozumiały dlań tekst służył raczej za wypełnienie czasu osobie usypiającej i w istocie zamykał się w monologowej autokomunikacji; jednak transpozycja tego układu na wydrukowany wiersz, przeznaczony głównie do cichej lektury, niewątpliwie paradoks ten wyostrza. Oczywiście nie chodzi tu o poezję zaplanowaną do głośnego czytania dzieciom przed snem przez dorosłych, która naturalnie kontynuuje dawną funkcję performatywną kołysanki. (Ta została omówiona w stosunkowo krótkiej Części II monografii). 
Nie chodzi również o „metakołysanki”, czyli wiersze opowiadające o akcie usypiania, o których interesująco pisze autorka w kilku kontekstach.

Krytyczny przegląd współczesnych teorii genologicznych, zręcznie skondensowany w Części I Kotysanka w ujęciu teoretycznym, służy badaczce - jak wcześniej zapowiedziała we wstępie zatytułowanym Między konstrukcja a anihilacja formy - do stworzenia synkretycznej metodologii, wchłaniającej ustalenia hermeneutyki, dekonstrukcjonizmu, nowego historyzmu oraz badań kulturowych nad codziennością i przestrzenią geograficzną. Istotnie, z tej bogatej oferty czerpie obficie, choć trudno mówić o syntezie metodologii czy nawet kompilacji, gdyż wybrane $\mathrm{z}$ nich narzędzia stosowane są wymiennie i okazjonalnie, w zależności od potrzeb analizowanego materiału. Pozwala to szczęśliwie uniknąć dogmatyzmu, forsującego mocne tezy kosztem subtelnie zindywidualizowanego przedmiotu badań. Wreszcie zadeklarowana jako łącząca wskazane opcje - i najbardziej wobec nich neutralna - technika „bliskiej lektury” okazuje się założeniem szczęśliwym i efektywnym, a jak słusznie sugeruje autorka, może służyć za uniwersalną procedurę badania każdego gatunku. Sadzę jednak, że zarówno znakomicie przeprowadzone interpretacje, jak i płynące z nich wnioski są raczej efektem rzetelnie wykonanej pracy badawczej i zależą $\mathrm{w}$ większym stopniu od talentu niż zastosowania tej czy innej metody.

Badaczka przekonująco dowodzi wszechobecności omawianego gatunku w poezji, jego najróżniejszych odmian, ech i śladów pozostawionych w licznych utworach, ale trudno zgodzić się z nazbyt zamaszystą generalizacją: „nie ma poety, który by nie napisał chociaż jednej kołysanki lub przynajmniej raz nie użył nawet w ograniczonym stopniu jej cech gatunkowych w swoim dziele" (s. 9).Z pewnością to przesada, jakkolwiek wszystko zależy od ustalonego zakresu gatunku, czyli uznania jego choćby najbardziej peryferycznych wyznaczników, które pozwolą mówić albo o jeszcze kołysance, albo już tylko „kołysankowości”, czyli inspiracji gatunkiem bądź jednym z aspektów utworu. Wybór koncepcji emergencyjnej - jako najbardziej elastycznej, tolerancyjnej i produktywnej - wydaje się z jednej strony optymalny, ale z drugiej mało użyteczny, gdyż nie gwarantuje finalnej precyzji rozpoznań w praktyce interpretacyjnej.

Określenie „bazy” cech gatunkowych nie budzi wątpliwości; natomiast zadaniem najtrudniejszym i wymuszającym arbitralność decyzji jest ustalenie horyzontu emergencji, czyli zmienności, która wielokierunkowo oddala analizowany materiał od wyznaczonego centrum. Pisze autorka: „Emergencyjna natura gatunku literackiego wynika nie tylko z jego biologistycznych 
koneksji czy darwinistycznych ujęć literatury, ale z prostego założenia, że ewolucja wpisana jest w jej logikę" (s. 39). Stwierdza ponadto, że emergent (cecha zmienna) istnieje na wyższym poziomie w stosunku do bazy, a więc rozwój gatunku może być wieloliniowy i nieprzewidywalny. Pytanie o granice zmienności pozostaje zatem otwarte, natomiast zadaniem badaczki staje się odnalezienie owych linii - niby promieni znikających na zamglonym horyzoncie i zbadanie ich przebiegu wyznaczonego przez poszczególne realizacje poetyckie. Już we wstępie rozpisuje potencjał zmian gatunkowych aż na jedenaście punktów, którym w przybliżeniu odpowiadają rozwinięcia w rozdziałach najdłuższej Części III książki. Możliwości zmian obejmują m.in.: realizację tylko wybranych cech gatunku z pominięciem pozostałych, nieograniczoną metaforyzację osób i sytuacji snu (nie tylko spokrewnionych ze śmiercią), zdolność przekazywania sprzecznych treści, wreszcie międzygatunkowe filiacje i fuzje.

Te i inne emergenty znajdują następnie uzasadnienie w konwencjach, nurtach, stylach autorskich i poszczególnych utworach, które wskazane kierunki modyfikacji rozwidlają w końcu w idiograficzną mozaikę portretowych zbliżeń. Długą listę autorów otwiera młodopolska poezja Wacława Rolicz-Liedera (interpretowana w kontekście filozofii Nietzcheańskiej), a zamykają „poeci piosenki”: Przybora, Osiecka, Kofta, Kaczmarski. A między nimi pojawia się wielobarwny tłum: Józef Czechowicz, któremu jako „klasykowi gatunku" poświęcony został osobny rozdział, Baczyński, Krahelska, Słobodnik, Jan Rostworowski, Iłłakowiczówna, Białoszewski, Aleksander Rymkiewicz, Bryll, Barańczak, Świetlicki, Zegadłowicz, Czuchnowski, Hartwig, Ficowski, Przyboś, Międzyrzecki, Liebert, Tymoteusz Karpowicz, Jan Rostworowski... Niektóre nazwiska powracają parokrotnie, ponieważ niemal każdy utwór uruchamia inne konteksty i ujawnia nową formę kołysankowej transformacji, toteż wydzielone w kolejnych rozdziałach tendencje rozszczepiają się na dalsze warianty i subwarianty. Trafnym rozwiązaniem wydaje się układ problemowy, gdyż choć nieraz rozmija się z chronologią historycznoliteracką, to pozwala zaobserwować, jak wielowariantowość stanowi efekt skrzyżowania emergencyjnych naruszeń różnych wyznaczników bazowych gatunku.

Najlepszą zasadą porządkującą wydaje się kryterium sytuacyjne, zwłaszcza gdy chodzi o kontrast między tradycyjnym celem bezpiecznego usypiania a grozą otaczającej rzeczywistości, między rytuałem codzienności a historią. W ten sposób zostaje wyodrębniona kołysanka zimowa, ale także emigracyjna, wojenna, kołysanka z getta i wiele innych odmian, nie zawsze 
sygnalizowanych w tytułach. Każda z nich wydaje się w jakiś sposób przekroczeniem gatunkowej normy albo ujęciem skrajnym. Może jednak za ekstremalną trzeba uznać Kotysankę rodzącej Krystyny Miłobędzkiej, gdyż relacjonując poród, zarazem zwraca się do odbiorcy prenatalnego, a więc ustanawia układ komunikacyjny niejako prospektywnie. Zresztą dobór egzemplifikacji wydaje się właśnie efektem poszukiwania „przekroczeń” szczególnie interesujących.

Mniej rewelacji przynosi ujęcie tematyczne, gdyż w tym porządku jesteśmy przygotowani na różnorodność, która obejmie niemal wszystkie możliwe motywy liryczne. Pojawia się więc: przemijanie, starość, śmierć i miłość, nihilizm i dekadentyzm, filozofia życia, dydaktyzm i satyra, wreszcie - ponawianie doświadczeń czasu minionego. I tu warto odnotować celne spostrzeżenie: „kołysankę można uznać za funkcję pamięci albo pamięć traktować jako semantyczną dominantę kołysanki" (s. 172).

Ciekawe są rozważania nad aliansami kołysanki i jej fuzją z innymi gatunkami: hymnem, erotykiem, lamentem, trenem, elegią, kolędą. Do tej listy dopisałbym jeszcze pieśń wielkopostną z przykładem: Dobranoc, Gtowo Święta. Związki te zostają jednak uporządkowane według kierunku wpływów, toteż badaczka zauważa, że „nazewnicze kompozycje są w istocie metaforami apozycyjnymi, w których pierwszy człon złożenia może stanowić specyficzny temat, drugi - nośnik" (s. 265). Wynika stąd, że istnieje różnica między np. ,kołysanką-trenem” a „trenem-kołysanką", która polega nie na innych proporcjach cech gatunkowych, lecz na kierunku relacji; chociaż w polu zainteresowania znalazły się tylko fuzje z kołysanką w pozycji tematu metafory.

W dwóch rozdziałach zostały omówione symetryczne energie omawianego gatunku, czy też „kołysankowości” jako tendencji stabilizującej rzeczywistość: pierwszą jest ochrona przed historią, drugą - afirmacja codzienności. Być może właśnie ta opozycja ujawnia szerszą perspektywę nowego opisu całych dziejów literatury, choć niestety znów binarnego jak wszystkie wykreślane w historii poezji "linie”? Niewykluczone jednak, że przyjmując tę parę za wektory badawcze sięgające poza horyzont analizowanego gatunku, nie wykreślilibyśmy żadnych nowych linii, lecz tylko przemianowali dawne wysłużone już dychotomie, np. nurtów „arkadyjskiego" z „katastroficznym”. Niemniej, wydaje się, że inspirująca siła tej monografii polega właśnie na tym, iż przedmiot refleksji genologicznej pozornie marginalny w literaturze, okazuje się niezwykle ekspansywny i prawie wszechobecny, mogąc służyć za nowy klucz interpretacyjny - zarówno egzystencji, jak i kultury. 
W całym przeglądzie zwracają uwagę fragmenty analityczne, wykazujące pewną autonomię. Niekiedy między nimi znajdziemy przenikliwe dygresje metodologiczne. Najlepszy wydaje się rozdział Dwuwersowa kołysanka Anny Kamieńskiej w perspektywie mikrologicznej. Między hermeneutyką a dekonstrukcja. Wskazany w tytule utwór staje się punktem wyjścia (ale nie pretekstem) do celnych uogólnień ujawniających nie tylko dojrzałość metodologiczną badaczki, lecz także jej inwencję teoretycznoliteracką. Świadczą o tym próby twórczej syntezy opcji uznawanych zwykle za opozycyjne, prowadzące do ściszonego skromnością manifestu metody własnej. Następnie autorka powraca do głównego nurtu swych dociekań i potwierdza ten ekskurs teoretyczny wirtuozowską analizą mikrologiczną Kotysanki Anny Kamieńskiej. Wydaje mi się, że trzeba żałować, że w ten sposób refleksja ta nie zostaje wyeksponowana i tonie w fali historycznoliterackiej idiografii czy też, skoro o kołysankach mowa - zostaje przez tę falę nieco „uśpiona”.

Myślę, że nie byłoby powodu do obszerniejszego komentowania tej imponującej monografii, a wystarczyłaby w pełni zasłużona rekomendacja, gdyby nie inspirowała ona żadnej glosy polemicznej, czyli zgłoszenia pewnego marginesu rozbieżności między doświadczeniem lektury a oczekiwaniami czytelnika. Na takim właśnie marginesie umieszczam więc pomysły, które nie są jednak ani krytyką decyzji autorki, ani roszczeniami malkontenta. Moje uwagi dotyczą innego nieco układu bogatego materiału, a tym samym możliwości zarówno zmiany przebiegu dyskursu, jak i przemeblowania implikowanej przezeń wirtualnej antologii tematyczno-genologicznej. Przegląd historyczny, który wypełnia większość książki, powoduje niewielkie stłumienie ujęcia teoretycznego i zaciera kontury gatunku - jeśli ten pojmowany ma być jednak jako inwariant, a nie tylko suma realizacji i przemian obserwowanych w poetyce historycznej. Upomniałbym się więc o dopełnienie diachronii przez próbę synchronii, obejmującej również wirtualną energię gatunku.

Podjęta przez monografistkę systematyka odmian gatunkowych i wariantów, wyprowadzonych z bazowego wzorca, wyłania się w tle interpretowanego materiału, toteż dominuje kryterium raczej tematyczne niż kompozycyjne - z wyjątkiem przejrzystej typologii filiacji kołysanki z innymi gatunkami. Wydaje się jednak, że nadrzędny podział powinna ustanawiać sytuacja komunikacyjna i sytuacja liryczna, czyli relacje nadawczo-odbiorcze skorelowane z układem ról (usypiający - usypiany), kierunkiem działania i celem. W dalszym planie - retoryka i styl wypowiedzi, a dopiero potem właściwości prozodyjne tekstu: budowa wiersza i odmiany kołysankowego 
rytmu - środki dające się opisać jako poziomy stylizacji. Zarówno cechy bazowe, jak i emergenty nie są bowiem luźnymi zbiorami, lecz układami hierarchicznymi, i może właśnie przyjęcie takiego założenia pozwoliłoby, jeśli nie wytyczyć ostry horyzont gatunku, to przynajmniej skuteczniej poruszać się po bezmiarze?

Na przeciwnym biegunie aktu usypiania - i dosłownego, i pojmowanego metaforycznie jako dowolna forma uspokajającej perswazji - sytuowałaby się inna liryka apelu - wzywająca do zmiany postawy, a zwłaszcza do czynu. Odwrotnością kołysanki byłaby zatem z pewnością tyrtejska „pobudka” (co ciekawe, tego terminu słowniki już nie pomijają!), np. wiersz Broniewskiego Bagnet na broń - jako mocna reprezentacja opozycji, gdyż nijak nie da się przez kołysankę (choćby najszerzej pojętą) zaanektować, co zresztą sugeruje antonimiczna nazwa gatunku. Antypody kołysanki jednak nie znalazły się w polu zainteresowań badaczki, choć analizuje ona przykłady różnych oddaleń od wzorca, w tym także formy sugerujące jego odwrócenie lub zaprzeczenie, takie jak „przebudzanka”. Pozwala to mówić o „antykołysance”, choć pomysł tak radykalnej nominacji autorka sama neutralizuje ostrożnym komentarzem, w którym słusznie stwierdza, że niemal każde użycie oznacza przekroczenie norm gatunkowych, toteż w ujęciu emergencyjnym nie może być mowy o transgresji. Natomiast: „specyficznymi «niekołysankami» można nazwać utwory realizujące negatywną poetykę gatunku, stale jednak budowane na wybranych cechach kołysanki" (s. 205). Najbardziej przekonującym przykładem w tej grupie wydaje się Czarna kołysanka Zagajewskiego, choć odwrócenie reguł polega w niej na prostej negacji: „Nie zaśniesz nigdy".

Lektura każdej monografii gatunku, zwłaszcza wspartej tak bogatą egzemplifikacją, rodzi pokusy dwojakiej rewizji: skłania z jednej strony do rozszerzenia o nieobjęty materiał, z drugiej do zawężenia pola obserwacji. Obydwie pokusy i obydwa postulaty świadczą o równie inspirującej mocy książki. Ujęcie redukcjonistyczne wydaje się trudniejsze, natomiast holistyczne mogłoby przerazić rozmiarem przedsięwzięcia badawczego, gdyż oznacza rozpatrzenie wprawdzie nie wszystkich wierszy onirycznych (cokolwiek to znaczy), ale przynajmniej tych z motywem zasypiania lub do zaśnięcia nakłaniających. Zresztą drogowskazy takich rozszerzeń sama autorka umieszcza na rozwidlającym się wielokrotnie szlaku dyskursu. Spróbujmy podążyć za jednym z nich, który ukaże sytuację komunikacyjną nie tyle graniczną, bo granic tu nie ma, ile możliwie najbardziej skomplikowaną a tym samym daleką od prostej illokucji usypiania. 
Interesującym przykładem odwróconej relacji snu i czuwania byłby wiersz Kazimierza Wierzyńskiego Nie lękaj się:

Nie lękaj się, otwórz drzwi,

Wejdź w mój sen,

Nie zbudzisz mnie:

Płynę po wielkiej rzece,

Od brzegu do brzegu ręce.

Serce na ciemnym dnie. ${ }^{2}$

Tu mówi osoba (już) śpiąca do osoby (jeszcze) czuwającej, zapraszając ją do własnego snu i zapewniając o nieszkodliwości takiej ingerencji. W drugiej strofie natomiast na tle wyrazistej symetrii z pierwszą sytuacja się relatywizuje, ponieważ w miejsce sugestii przemawiania „ja” z pozycji śpiącego pojawia się nagle deklaracja mimochodem przecząca wcześniejszemu zaproszeniu:

Nie lękaj się, otwórz drzwi,

Wejdź do pokoju,

Nie zbudzisz mnie:

Nie śpię, szukam po ciemku

Brzegów, które trzymałem w ręku,

Jakiegoś gruntu na jakimś dnie ${ }^{3}$.

Drugie zapewnienie, „nie zbudzisz mnie”, ma zatem odwrotną motywację: nie można zbudzić tego, kto czuwa - chyba że sen jest piętrowy, jak w koszmarach Leśmiana. Między pierwszą a drugą strofą musiało więc nastąpić przebudzenie - poza słowami, stłumione i prawie niezauważalne przez dominację paralelizmów i powtórzeń. Po śnie pozostały typowe w poetyce onirycznej motywy akwatyczne z metaforą rzeki i pływania - stylem co prawda niby klasycznym, a jednak dość osobliwym, skoro ręce sięgają brzegów. Wyrażona na jawie tęsknota do wyśnionych brzegów i dna, które zastępuje pewny "grunt" rzeczywistości, może być rozwinięciem toposu „życie jest snem” albo jego odwróceniem: „sen jest (właściwym) życiem”.

2 K. Wierzyński Nie lękaj się, w tegoż Wiersze wybrane, Wyboru dokonał i wstępem opatrzył M. Sprusiński, Warszawa 1979, s. 223.

3 Tamże. 
Powtórzenia i toniczność wiersza (trójzestrojowca), a zatem jego potencjalna meliczność dobrze mieszczą się we wzorcu stylistycznym kołysanki; natomiast budzi wątpliwości sytuacja liryczna i kompozycja utworu. Wprawdzie nikt nikogo nie usypia i brak typowych zachęt „uśnij”, ,zaśnij”, ,śpij”, ,lulaj", ale taki zamiar jest przecież implikowany przez podwojone zaproszenie: najpierw do własnego snu, potem do wrażeń sennych wyniesionych na jawę. Zasypianie okazuje się jednak niekoniecznym warunkiem współudziału w świecie cudzego marzenia sennego. Może to przykład „kołysanki implikowanej”, a może już „niekołysanka”? Wskazuję tylko na niepewny zakres gatunku, który zresztą monografistka sobie uświadamia, ostrożnie wytyczając jego rozległe pogranicza (bez granic) w obfitości analizowanych tekstów.

Na koniec jeszcze drobna uwaga do podtytułu, wyznaczającego zasięg chronologiczny badanego materiału. Dotyczy ona zresztą nie tylko omawianej monografii, lecz powszechnej dziś praktyki tytułowania, która znieczula na hiperboliczny skrót myślowy, sugerując niefortunne roszczenia temporalne. W połowie drugiej zaledwie dekady XXI stulecia nie powinno się mówić o „wieku” jak o zamkniętej przeszłości. Jeśli dla dzisiejszego odbiorcy umowność takiego okolicznika czasu jest w pełni zrozumiała i łatwo go sobie sprecyzuje jako „początek wieku”, to za sto lat określenie zakresu monografii będzie wprowadzać w błąd, sprostowany w bibliografii tylko przez datę wydania, która wykluczy prekognicję i prospektywność omówienia. Może to uwaga pedanta, wykazującego przedwczesną troskę (choć ta musi być zawsze przedwczesna, inaczej zamieni się w żal), ale warta rozważenia, by w tytułach innych prac powściągnąć podobną przesadę.

Oczywiście nie można tak śmiało prognozować zdarzeń literackich, a pośród nich i kierunków dalszej emergencji kołysanki, by przewidzieć je na najbliższych 75 lat. Zakładam bowiem, że książka ta przetrwa na półkach bibliotek jako klasyka monografii genologicznej znacznie dłużej. Wydaje się, że podobna staroświecka wiara w trwałość dyskursu powinna przyświecać wszystkim - choć już coraz mniej licznym - monografistom. Zwłaszcza że w tym wypadku otrzymaliśmy książkę, która mówiąc o kołysance, nie tylko nie uśpi czytelnika, lecz w wielu miejscach nie da zasnąć genologom. 


\section{Abstract}

\section{Piotr Michałowski}

UNIVERSITY OF SZCZECIN

A Lullaby Awakening Genre Studies

Review: K. Wądolny-Tatar, Kołysanka w liryce XX XXXI wieku: Emergencja gatunku literackiego [The Lullaby in Lyrical Poetry of the Twentieth and Twenty-First Centuries: The Emergence of a Literary Genre], Wydaw. Naukowe Uniw. Pegdagogicznego, Cracow 2014.

\section{Keywords}

Polish poetry, second-person poetry, lullaby, genre studies, poetic genres 